\title{
The Effect of a Drug-resistance Factor on Recombination and Repair of DNA in Escherichia coli $\mathrm{K} 12$
}

\author{
By P. OLIVER \\ Department of Genetics, University of Cambridge, \\ Downing Street, Cambridge CB2 $3 E H$ \\ AND K. A. STACEY \\ Biological Laboratory, University of Kent, Canterbury $\mathrm{CT}_{2}{ }_{7} \mathrm{NJ}$
}

(Received I4 January 1977)

\begin{abstract}
The presence in recipient strains of Escherichia coli $\mathrm{KI} 2$ of the plasmid R46 greatly reduced the yield of recombinants from crosses with several Hfr strains and virtually abolished the formation of recombinants by P I transduction without, however, significantly affecting the transfer of the F prime from a strain carrying Fgal. The R46 plasmid had paradoxical effects on mutability: it appeared to enhance the yield of mutants following irradiation with ultraviolet light but it reduced the number of mutants detectable in unirradiated cultures. The effects of this plasmid on ultraviolet light survival of the wild type and several mutants defective for recombination and repair have been measured and the results, in the main, confirm similar observations by Tweats et al. (I976). Not only is the survival of the strain harbouring R46 greater than that of the parent strain in all the cases studied, but the survival of ultraviolet irradiated bacteriophage $\lambda$ is also greater.
\end{abstract}

\section{INTRODUCTION}

A number of enzymic mechanisms have been suggested for the processes of repair and recombination of DNA in the bacterium Escherichia coli KI2 (for reviews see Grossman et al., 1975; Clark, 1973). In addition to the chromosomal gene functions involved, identified by rec, $u v r$, lex and $s b c$ mutations, a number of extrachromosomal elements appear to be able to influence the repair and recombination of DNA. The increased survival after ultraviolet (u.v.) irradiation of strains carrying ColI compared with their non-colicinogenic parent strains was first described by Howarth (1965) and the effects of other bacterial plasmids which confer on their hosts an increased resistance to DNA damaging agents have been discussed (Drabble \& Stocker, I968; Marsh \& Smith, I969; Siccardi, I969). With the increased survival there is a concomitant increase in the induced mutation rate (Krishnapillai, 1975) and in Salmonella typhimurium the spontaneous mutation rate is also increased (Mortelmans \& Stocker, personal communication). However, the mechanism(s) responsible for these phenomena are unknown although one plasmid, R-Utrecht, has been shown to code for a new DNA polymerase (MacPhee, 1974). As certain of the gene products that are involved in the repair of DNA are also required for recombination, the effect of R46 (= RI8I8 = R-Brighton), a plasmid which increases the resistance of $S$. typhimurium to u.v. light, was investigated. In this paper the effects of this plasmid on u.v. survival and recombination in wild-type strains and in certain mutant strains are reported. With the exception of the results relating to recA strains, the data confirm and extend the observations concerned with the u.v. survival of $\mathrm{R}_{4} 6^{+}$strains reported by Tweats et al. 
Table I. Bacteria, plasmids and bacteriophage

\begin{tabular}{|c|c|c|}
\hline Strain designation & Relevant genotype & Source \\
\hline \multicolumn{3}{|c|}{ E. coli $\mathrm{KI} 2 \mathrm{~F}^{-}$strains } \\
\hline S49I & pro his udp $\lambda^{-}$ & R. G. Lloyd \\
\hline $\mathbf{Z F}^{-}$ & met $\lambda^{\mathrm{R}} \lambda-\mathrm{Sm}^{\mathrm{S}}$ & Laboratory stock strain \\
\hline 24 & thr leu thi & E. Meynell \\
\hline SIOO. & $\mathrm{K} 12$ prototroph & R. G. Lloyd \\
\hline ABI 886 & thr leu thi pro his arg uvrA & P. Howard-Flanders \\
\hline KL4O3 & leu pro his thy A polAI & K. B. Low \\
\hline POIO2 & as $\mathrm{S} 49 \mathrm{I}$, except rec $A 56 \mathrm{his}^{+}$ & $\begin{array}{l}\text { Exconjugant from s49I } \times \\
\text { KLI6-99 mating }\end{array}$ \\
\hline АT302I & his leu pdxA met thi str $A$ ara & A. Taylor \\
\hline \multicolumn{3}{|c|}{ E. coli $\mathrm{K} 12 \mathrm{~F}^{+}$strains } \\
\hline HfrH & met $\mathrm{Sm}^{\mathrm{s}}$ & Laboratory stock strain \\
\hline KLI6 & $\mathrm{Sm}^{\mathrm{s}}$ & K. B. Low \\
\hline KL98 & $\mathrm{Sm}^{\mathrm{S}}$ & K. B. Low \\
\hline W4520 & gal Sm $\mathrm{Sm}^{\mathrm{s}}$ Fal & P. Howard-Flanders \\
\hline \multicolumn{3}{|l|}{ Plasmids } \\
\hline $\mathrm{R}_{46}$ & $\mathrm{Amp}^{\mathrm{R}} \mathrm{Tc}^{\mathrm{R}} \mathrm{Sm}^{\mathrm{R}} \mathbf{P c}^{\mathrm{R}} \mathrm{Su}^{\mathrm{R}}$ & E. Meynell \\
\hline Fgal & $\mathrm{gal}^{+}$ & (in strain w4520) \\
\hline \multicolumn{3}{|l|}{ Bacteriophage } \\
\hline PI kc & & Laboratory stock strain \\
\hline
\end{tabular}

(I976). This work was initiated because R46 had been shown to affect the phenotype of a novel mutant of $E$. coli $\mathrm{KI} 2$ which, in the absence of $\mathrm{R} 46$, could not be transduced using phage PI (Stacey \& Oliver, 1977): these results will be reported later.

\section{METHODS}

Bacteria and bacteriophage. The strains used in this investigation are listed in Table $\mathbf{I}$.

Media and genetic manipulations. The composition of the media and the methods used in the experiments were described in detail by Stacey \& Oliver (1977).

Ultraviolet irradiation. For the irradiation of $\mathrm{rec}^{+}$, pol $A$, uvr $A$ and lex mutants, a Hanovia lamp (CHI/I367) which delivered a dose of $3 \mathrm{~J} \mathrm{~m}^{-2} \mathrm{~s}^{-1}$ was used. For rec $A$ mutants, a Philips lamp which had one-tenth of the power of the Hanovia lamp and delivered a dose of $0.3 \mathrm{~J} \mathrm{~m}^{-2} \mathrm{~s}^{-1}$ was used.

Transfer of R46. The drug resistance factor R46 was obtained in a host strain which was lysogenic for bacteriophage $\lambda$ (strain 24 from Dr E. Meynell). As the products of the red genes of $\lambda$ can effect the survival of the host after irradiation (Trgovcevic \& Rupp, 1974) and can increase the yield of recombinants (Signer \& Weil, I968; Lloyd, I97I ; Oliver, unpublished results), the plasmid was first transferred to the non-lysogenic $\lambda$-resistant strain, $\mathbf{Z} \mathbf{F}^{-}$. From this strain the plasmid was transferred into the strains used in this investigation.

\section{RESULTS}

\section{Survival following ultraviolet irradiation}

Strains containing R46 exhibited an increased survival following u.v. irradiation when compared with their parent strains (Fig. I). The increase in survival was most apparent with the wild-type strain, S49I. A possible explanation for the protection afforded by R46 is that the plasmid codes for a 'repair system' which removes damage which might otherwise result in lethality. This system might be analogous to one of the repair systems that have been identified in $E$. coli. To test this suggestion the plasmid was transferred to various strains that were deficient in known repair functions.

The plasmid afforded protection to a $u v r A$ mutant which is deficient in the endonucleolytic incision step of the excision repair pathway (Braun \& Grossman, 1974). It also gave protection to a polA mutant which is deficient in DNA polymerase $I$, thought to be involved in the excision and resynthesis stages of repair (Fig. I). Protection of $\mathrm{rec} B$ and $\mathrm{rec} C$ strains by $\mathrm{R} 46$ has been reported by Tweats et al. (1976), but they did not detect any protection in 


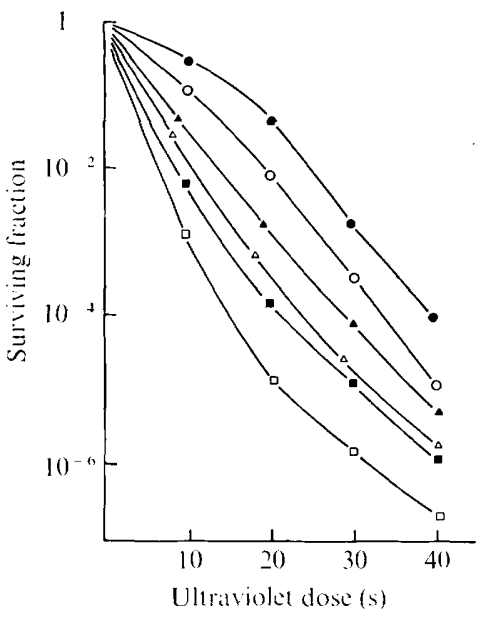

Fig. I

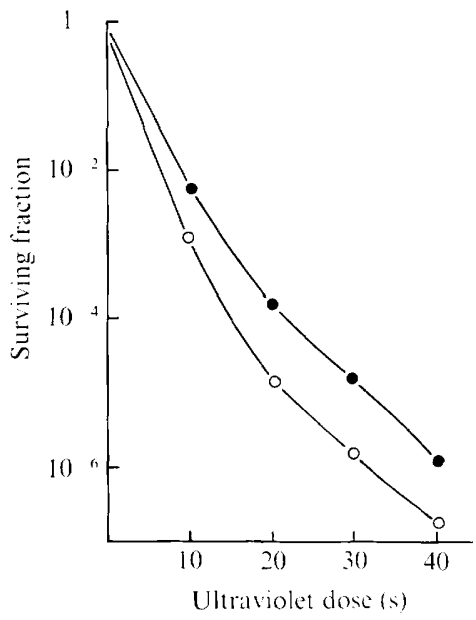

Fig. 2

Fig. I. Ultraviolet light survival of wild-type, $u v r A$ and $p o l A$ strains and their derivatives containing R46: $\bigcirc$, S49I; O, S49I(R46); $\square$, ABI886; $\mathbf{a}, \mathrm{ABI} 886(\mathrm{R} 46) ; \triangle, \mathrm{KL} 403 ; \Delta, \mathrm{KL}_{403}(\mathrm{R} 46)$.

Fig. 2. Ultraviolet light survival of a $\operatorname{rec} A$ mutant and its derivative containing R46: $\bigcirc$, PoI02; , POIO2(R46).

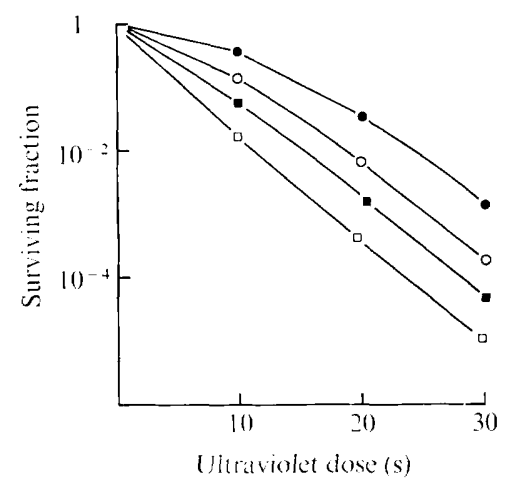

Fig. 3. Survival of ultraviolet light irradiated $\lambda \mathrm{cI}$ on wild-type and $\operatorname{rec} A$ strains and their derivatives containing R46: O, S49I; O, S49I(R46); $\square$, POIO2; E, POIO2(R46).

rec $A$ strains. Using a u.v. source emitting much less radiation, we have detected protection in $\operatorname{rec} A$ strains (Fig. 2). Moreover irradiated $\lambda \mathrm{cI}$ plated with higher efficiency on $\operatorname{rec} A(\mathrm{R} 46)$ strains than on recA mutants (Fig. 3).

Thus R46 increases the survival of both repair-proficient and repair-deficient bacteria, although in the case of the mutant strains the plasmid does not restore the u.v. survival to that of the wild-type strain. The unrelated drug resistance factor R I-I9 had no effect on the survival of these strains, implying that the protection conferred by R 46 required genes carried by the plasmid and was not just a physical effect due to an increase in DNA content.

In addition to the increased resistance to irradiation of the host strain the presence of the plasmid increased the plating efficiency of irradiated bacteriophage; when irradiated bacteriophage $\lambda \mathrm{cI}$ was plated on strains S49I and S49I(R46) there was an increased survival on the strain bearing the plasmid (Fig. 3).

\section{Mutation rate}

The plasmid R46 exerted an antimutator effect on the spontaneous reversion rates of the auxotrophic markers of strain S49I (Table 2), and the frequency of nalidixic acid resistant 
Table 2. Effect of $\mathrm{R} 46$ on mutation rates

\begin{tabular}{|c|c|c|c|c|}
\hline \multirow[b]{2}{*}{ Strain } & \multirow[b]{2}{*}{ Mutagen } & \multicolumn{3}{|c|}{ Frequency of mutation per survivor } \\
\hline & & pro $^{+}$ & his $^{+}$ & $\mathrm{Nal}^{\mathrm{R}}$ \\
\hline S491 & none & $5 \cdot 3 \times 10^{-7}$ & $3.1 \times 10^{-7}$ & $2.3 \times 10^{-7}$ \\
\hline S49I(R46) & none & $3.2 \times 10^{-8}$ & $1 \cdot 2 \times 10^{-8}$ & $3.4 \times 10^{-8}$ \\
\hline S49I & u.v.* & $8.2 \times 10^{-6}$ & ND & $4.1 \times 10^{-6}$ \\
\hline S49I(R46) & u.v.* & $9.8 \times 10^{-4}$ & ND & $6.3 \times 10^{-5}$ \\
\hline
\end{tabular}

ND, Not determined.

* U.v. dose: $3 \mathrm{~J} \mathrm{~m}^{-2} \mathrm{~s}^{-1}$. The survival, $N / N_{0}$, was $10 \%$ for $\mathrm{s} 49 \mathrm{I}$ and $20 \%$ for $\mathrm{s} 49 \mathrm{I}(\mathrm{R} 46)$.

Table 3. Recombination proficiency of strains containing $\mathrm{R} 46$, as measured by conjugal mating

\begin{tabular}{|c|c|c|c|c|}
\hline Recipient & Donor & $\begin{array}{l}\text { Selected } \\
\text { marker* }\end{array}$ & $\begin{array}{l}\text { Recombinants }\left(\mathrm{ml}^{-1} \text { ) }\right. \\
\text { (per donor) } \dagger\end{array}$ & $\begin{array}{c}\text { Recombination } \\
\text { deficiency } \ddagger\end{array}$ \\
\hline S49I & KLI 6 & $h i s^{+}$ & $3.37 \times 10^{-3}$ & I \\
\hline S49I (R46) & KLI 6 & $h_{i s}^{+}$ & $3.25 \times 10^{-4}$ & $9.6 \times 10^{-2}$ \\
\hline S49I & KL98 & $h i s^{+}$ & $\mathrm{I} \cdot 43 \times 10^{-1}$ & I \\
\hline S49I(R46) & KL98 & $h i s^{+}$ & $7.5 \times 10^{-6}$ & $5.2 \times 10^{-5}$ \\
\hline S49 I & HfrH & pro $^{+}$ & $43 \times 10^{-1}$ & I \\
\hline S49I $\left(R_{46}\right)$ & $\mathrm{HfrH}$ & pro $^{+}$ & $1 \cdot 2 \times 10^{-4}$ & $2 \cdot 8 \times 10^{-4}$ \\
\hline S49 I & sioo(Fgal) & $\mathrm{gal}^{+}$ & $9.0 \times 10^{-2}$ & I \\
\hline S49I(R46) & sioo(Fgal) & $\mathrm{gal}^{+}$ & $6.8 \times 10^{-2}$ & $7.5 \times 10^{-1}$ \\
\hline
\end{tabular}

* Counter-selection of donor for resistance to azauracil.

$\dagger$ Checked by restreaking.

+ Ratio of the no. of recombinants formed to the no. of recombinants formed with s49r.

mutants was similarly reduced. However, the mutation rates after u.v. irradiation were much enhanced (Table 2).

\section{Effect on recombination}

When the plasmid was present in the recipient strain of a conjugation mating there was a dramatic reduction in the yield of recombinants (Table 3 ). With strain S49I(R46) as recipient the reduction in recombinants was greater for strain $\mathrm{HfrH}$ than for KLI6. The inability to produce recombinants was not a result of the ampicillin present in the selection plates as no more recombinants were detected when it was omitted or when tetracyline was used in its place to ensure that the recombinants contained R46. There was, however, little difference in the ability of strains S49I and S49I $\left(R_{4} 6\right)$ to receive the Fgal factor, which implies that $\mathrm{R}_{4} 6$ exerts its effect at the level of recombination and not by reducing the ability of the recipient to accept donor DNA. [This experiment is possible because R46 is compatible with $\mathrm{F}^{+}$(Hedges, 1972)]. $\operatorname{rec} B$ mutants, which are defective in recombination, yielded even fewer recombinants when carrying R46. As strain s49I was unsuitable for measuring the linkage of unselected markers, the plasmid was transferred to AT302I and this strain was used as a recipient in matings with $\mathrm{HfrH.AT737}$ as donor. Although the number of $\mathrm{Leu}^{+}$recombinants was low it was possible to score the unselected $\operatorname{ara}$ and $p d x A$ markers. The linkage of these markers was greatly disturbed (Table 4).

When strains carrying R46 were used as recipients in generalized transduction experiments very few recombinants could be detected (Table 5). This was not due to poor adsorption of the bacteriophage as R46 had no effect on the efficiency of plating of PI or on the frequency of lysogenization by PICM (Oliver, unpublished experiments).

The reduction in the yield of recombinants and in the linkage hetween genetic markers is characteristic of restriction of the transferred DNA. However no new restriction or modification system has been demonstrated in bacteria containing R46 (Hedges, I972) although other members of the $\mathrm{N}$ incompatibility group do code for the EcoRII restriction and modi- 
Table 4. Effect of $R 46$ on the co-inheritance of unselected proximal markers in matings with $\mathrm{HfrH}$

Exponentially growing cultures of donor $(\mathrm{HfrH})$ and recipient strains were mixed in a ratio of $\mathrm{I}$ : 10 donor to recipient cells. Matings were carried out in a static water bath at $37^{\circ} \mathrm{C}$ for $30 \mathrm{~min}$.

\begin{tabular}{|c|c|c|c|}
\hline \multirow[b]{2}{*}{ Recipient } & \multirow{2}{*}{$\begin{array}{c}\text { Selected } \\
\text { marker } \\
\text { leu }^{+}\end{array}$} & \multicolumn{2}{|c|}{$\begin{array}{l}\text { Co-inheritance of unselected } \\
\text { proximal markers }(\%)\end{array}$} \\
\hline & & $a r a^{+}$ & $p d x A^{+}$ \\
\hline AT302I & 100 & 94 & 93 \\
\hline AT302 I (R46) & 50 & 28 & 49 \\
\hline
\end{tabular}

Table 5. Effect of $R 46$ on the transduction of chromosomal markers by phage $P_{\mathbf{I}}$

Transduction frequency per adsorbed phage

$\begin{array}{llrc}\text { Donor } & \text { Recipient } & \text { pro }^{+} & \text {his }^{+} \\ \text {PI (SIOO) } & \text { S49I } & 4.2 \times 10^{-6} & 8.3 \times 10^{-6} \\ \text { PI (SIOO) } & \text { S49I(R46) } & <\mathrm{I} \times 10^{-9} & <\mathrm{I} \times 10^{-9}\end{array}$

fication system. Moreover when both donor and recipient cells contain R46 there is still a reduction in the yield of recombinants (Jones \& Oliver, unpublished results).

A similar plasmid, R-Utrecht, has also been reported to increase survival of the host bacterium, due to a plasmid-coded DNA polymerase with similarities to the polA gene product (MacPhee, I974). If a similar mechanism is responsible for these experimental results, then $\mathrm{R} 46$ should also code for a DNA polymerase. Indeed R46 does partially restore the resistance to u.v. irradiation to a polA mutant, but if R46 codes for a DNA polymerase that can replace the polA gene product then the presence of R46 should enable a polA mutant to support the growth of $\lambda s p i$ mutants which are not able to grow in strains lacking polymerase I (Zissler, Signer \& Schafer, 197I). There was no difference in the efficiency of plating of $\lambda$ bioII (a deletion mutant of $\lambda$ which has the Spi- phenotype) on KL403, a polA mutant, or KL403 (R46). It is likely, therefore, that R46 does not have a polymerase I-like gene product.

\section{DISCUSSION}

These experiments demonstrate that the plasmid R46 affects recombination following transduction or conjugation. This is in addition to the mutator effect reported to occur in Salmonella typhimurium (Mortelmans \& Stocker, personal communication) and the resistance to u.v. light that it confers on both $S$. typhimurium and $E$. coli (Tweats et al., 1976).

The increased survival after u.v. irradiation conferred by ColI and R 46 could be explained by a plasmid-coded endonuclease which causes single-strand 'nicks' in double-stranded DNA that supplement, or partially replace in $u v r$ strains, the endonucleolytic action of the $u v r^{+}$gene products (Tweats \& Smith, 1974). Such nicks have been observed in plasmid DNA in cells subject to thymine starvation (Freifelder, I969; Pinney, Bremer \& Smith, 1974). The presence of a nuclease of this kind might explain the effects reported here of R46 on recombination because it might either diminish the life-time of the recombination intermediate or shorten the length of DNA involved, However, there are a number of observations that imply that single-strand breaks encourage recombination. The recombinogenic effect of u.v. irradiation depends on a functional $u v r$ system and is not seen in $u v r$ strains. Moreover, the effect of R46 on mutation is paradoxical: it is an anti-mutator in unirradiated strains but it enhances u.v.-induced mutation rates. An explanation for part of this difference may lie in the suggestion of Pinney et al. (1974) that the nuclease is induced by thymine starvation, and therefore, by analogy, perhaps by u.v. radiation. If the nuclease is induced its effects may be different when the amount of DNA damage is quite different. The change in the extent of co-inheritance of closely linked but unselected markers caused by the presence of 
R46 in the zygotes is consistent with DNA damage. A similar loss of linkage and increase in multiple crossing over has been observed several times in the recombinants obtained after u.v. irradiation of the Hfr donor immediately before conjugation (see Stacey, Evenchik \& Hayes, 1969).

Other plasmids that have been reported to affect the survival of bacteria after treatment with DNA damaging agents include ColI (Howarth, I965), certain drug resistance factors (Marsh \& Smith, I969) and some sex factors of Pseudomonas (Krishnapillai, 1975). The drug resistance factor RI-19 has recently been shown to afford protection against ultraviolet light to $\operatorname{rec} A$ strains (Dr J. Holton, personal communication). The closely related $\mathrm{N}$ group plasmids, R45 and R48, confer radioresistance on their hosts but do not affect the yield of recombinants after conjugation or transduction. It is, therefore, not yet possible to decide whether the three changes in phenotype that the presence of R46 causes are the result of a single gene or not.

This work was initiated at the University of Kent whilst P.O. was the holder of an MRC postgraduate scholarship.

\section{REFERENCES}

Braun, A. \& Grossman, L. (1974). An endonuclease from Escherichia coli that acts preferentially on UV-irradiated DNA and is absent from $u v r A$ and uvr B mutants. Proceedings of the National Academy of Sciences of the United States of America $\mathbf{7 1}$, I838-I 842.

Clark, A. J. (1973). Recombination deficient mutants of $E$. coli and other bacteria. Annual Review of Genetics 7, 67-86.

Drabble, W. T. \& Stocker, B. A. D. (I968). R (transmissible drug-resistance) factors in Salmonella typhimurium: pattern of transduction by phage $\mathrm{P}_{22}$ and ultraviolet protection effect. Journal of General Microbiology 53, 109-1 23.

FreIFELDER, D. (1969). Single strand breaks in bacterial DNA associated with thymine starvation. Journal of Molecular Biology 45, I-7.

Grossman, L., Braun, A., Feldberg, R. \& MahLER, I. (1975). Enzymatic repair of DNA. Annual Review of Biochemistry 44, I9-43.

HedGes, R. W. (1972). Phenotypic characterisation of $\mathrm{fi}^{-} \mathrm{R}$ factors determining the restriction and modification hspII specificity. Molecular and General Genetics Ir5, 225-233.

HowARTH, S. (1965). Resistance to the bactericidal effect of ultraviolet radiation conferred on enterobacteria by the colicine factor coll. Journal of General Microbiology 40, 43-55.

KRISHNAPILLAI, V. (1975). Resistance to ultraviolet light and enhanced mutagenesis conferred by Pseudomonas aeruginosa plasmids. Mutation Research 29, 363-372.

LLOYD, R. G. (I97I). Recombination deficient mutants of Escherichia coli $\mathrm{KI}$ 2. Ph.D. thesis, University of Sussex.

MAcPhee, D. (1974). DNA polymerase activity determined by the ultraviolet protecting activity of plasmid R-Utrecht. Nature, London 251, 432434.

MARSH, E. B. \& SMITH, D. H. (1969). R-factors improving survival of Escherichia coli KI 2 aftor ultraviolet irradiation. Journal of Bacteriology 1oo, I28-139.
Pinney, R. J., Bremer, K. \& Smith, J. T. (I974). R factor elimination by inhibition of thymidylate synthetase (fluorodeoxyavidine and showdomycin) and the occurrence of SS breaks in plasmid DNA. Molecular and General Genetics I33, I63-174.

SicCARdi, A. G. (1969). Effect of $R$ factors and other plasmids on ultraviolet susceptibility and host-cell reactivation property of Escherichia coli. Journal of Bacteriology 100, 337-346.

SIGNER, E. R. \& WEIL, J. (I968). Recombination in bacteriophage $\lambda$. I. Mutants deficient in general recombination. Journal of Molecular Biology 34, 26I-27I.

Stacey, K. A., Evenchik, Z. \& Hayes, W. (I969). The effects of ultraviolet irradiation on the fertility of $\mathrm{F}^{+}$and $\mathrm{Hfr}$ strains of Escherichia coli $\mathrm{KI} 2$ defective for the repair of damaged DNA. Journal of General Microbiology 59, I85-191.

Stacey, K. A. \& Oliver, P. (I977). A novel pleiotropic mutation in Escherichia coli $\mathrm{KI} 2$ which affects transduction, transformation and rates of mutation. Journal of General Microbiology 98 , $569-578$.

Trgovcevic, Z. \& Rupp, W. D. (1974). Interaction of bacterial and lambda phage recombination systems in the X-ray sensitivity of Escherichia coli KI 2. Proceedings of the National Academy of Sciences of the United States of America 71, 503-506.

Tweats, D. J. \& Sмiтh, J. T. (I974). R-factor mediated nuclease activity involved in thymineless elimination. Journal of Bacteriology 118, 790-795.

Tweats, D. J., Thompson, M. J., Pinney, R. J. \& Sмттн, J. T. (I976). $\mathrm{R}$ factor-mediated resistance to ultraviolet light in strains of Escherichia coli deficient in known repair functions. Journal of General Microbiology 93, IO3-I 10.

Zissler, J., Signer, E. \& Schafer, F. (I97I). The role of recombination in the growth of bacteriophage lamda. I. The gamma gene. In The Bacteriophage Lambda, pp. 455-468. Edited by A. D. Hershey, New York: Cold Spring Harbor Laboratory. 